\title{
Analysis of the effect of unemployment insurance on enterprise management
}

\author{
WEI Rui-qing \\ Inner Mongolia University of Finance and Economics, Inner Mongolia Hohhot City 010070 \\ E-mial: nmwrq2007@126.com
}

\begin{abstract}
Unemployment insurance can provide a certain level of economic subsidies for the temporarily unemployed workers to ensure their basic survival needs. The unemployment insurance becomes a welfare system with protection function of enterprise salary system, so majority of workers will focus on the payment of the social insurance in the enterprise, such as unemployment insurance. This paper establishes an unemployment insurance enterprise management forecast model to solve the complex problems such as the influence of unemployment insurance payment on enterprise management (current employees' recruitment, welfare systems design etc.). It takes candidates and potential candidates in the labor market as the main objects, the survey method to obtain the sample data, and multiple linear regression model to analyze the impact of unemployment insurance on corporate recruitment, corporate consolidation competitive. The results show that the unemployment insurance can significantly improve the competitiveness of enterprises in the labor market and the attractiveness of the candidates, and enhance the corporate external image while bringing far lower economic pressure than the invisible receipts enterprises obtained.
\end{abstract}

Keywords: Unemployment insurance; Human Resource Management; Recruitment; Multivariate linear regression model

CLC

\section{INTRODUCTION}

With the deepening of the reform of China's market economy, external economic environment have more and more serious impact on China, so enterprises have to face a more volatile market environment. Due to lack of practical business management experience, when Chinese enterprises face severe economic crisis, such as the financial crisis and the debt crisis, usually they reduce costs and maintain enterprise of basic operators only by simple cuts and layoffs. Layoffs will affect economic income of the employees, and have an enormous impact on their mentalities and families. The survey results show that for middle-aged workers, when select jobs in labor market, medical insurance, unemployment insurance and other social insurance will be the priority consideration, followed by the salary compensation ${ }^{[1 \sim 3]}$. The Survey results of workers' keen degree on unemployment insurance are shown in Figure 1:

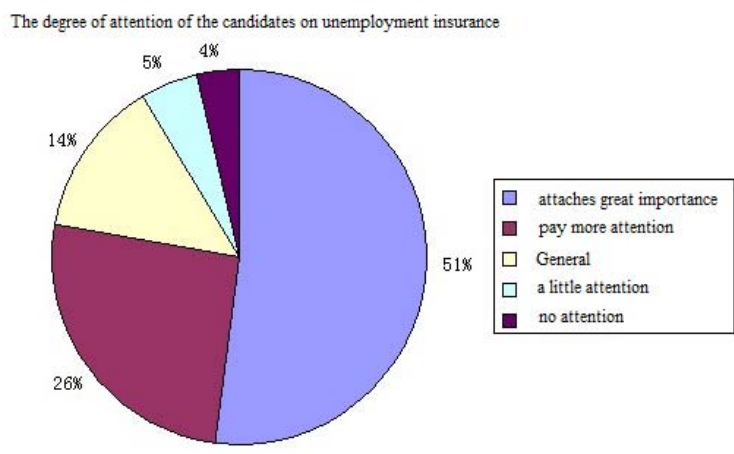

Figure 1 Workers' keen degree on unemployment insurance

If the enterprise provides the basic unemployment insurance, it can largely ease the mental stress and pressure of life of staffs during the turnover process, and provide employees with a short-term source of economic $^{[4 \sim 5]}$. Although unemployment insurance cannot bring the long-term economic security for workers, it reflects the people-oriented enterprise which is also employee benefits design principles. Even if our current unemployment insurance and Medicaid amount is relatively low, they form a powerful influence to workers. Even young candidates in the candidate process will put more weight on unemployment insurance, maternity insurance and other social insurance than the salary competitiveness. China is mandatory for enterprises and institutions to pay basic social insurance for employees such as unemployment insurance and maternity insurance. However, in this case, there are still some businesses find ways to escape from paying insurance for employees, ignoring the positive impact of unemployment insurance bringing to the enterprise management. The paper studies the influence of unemployment insurance on enterprise management by investigation and empirical research methods.

\section{THE MAIN IMPACT OF THE UNEMPLOYMENT INSURANCE ON ENTERPRISE MANAGEMENT}

Unemployment insurance provides income subsidies and medical subsidies for temporarily unemployed workers, in order to ensure the basic survival needs of life of the unemployed. Unemployment insurance becomes a welfare system with protection function of the enterprise salary system. Unemployment insurance mainly affects the following aspects of business management:

First, the payment of unemployment insurance reflects the enterprise management concept of people-oriented enterprises and enhances the corporate image of the company in the labor market. Unemployment insurance is mainly established to protect the basic living of employees unemployed who used to have wage income. Its coverage 
includes the majority of the members of the company workforce. The process of unemployment insurance system from establishment to promotion reflects the positive efforts of the government on workers' income security. Enterprises and institutions strictly abiding state regulations to pay unemployment insurance for based unit of employees reflect the humane and reasonable of company's compensation system and the corporate image in the labor market. Enterprises need long-term efforts instead of a short period time to shape a positive corporate image. Good corporate image will bring more high-quality staffs and enhance the efficiency of the entire enterprise. Therefore, unemployment insurance has very positive effects for the image of corporate employers in the labor market.

Second, unemployment insurance paid by companies will increase the cost, but it will bring a lot of hidden income to the enterprise. Unemployment insurance is enforced by national laws and regulations. In accordance with the provisions, companies and their employees within the coverage of the unemployment insurance system must participate in the unemployment insurance and fulfill payment obligations. According to the amount of employee wages, companies need to pay a certain percentage of unemployment insurance for employees monthly, usually $1 \%$ of wages and salaries. Obviously, unemployment insurance payment will bring some management costs, but the attractiveness of unemployment insurance to talented employees will play a significant role in work efficiency. The invisible income, economic benefits brought by the enhancement of efficiency of the enterprises, will be far more than the cost of management caused by the unemployment insurance. according to statistics of the Ministry of Human Resources and Social Security, quantifiable loss caused by the departure of ordinary employee to the enterprise is usually three months' wages for the employees, and the economic losses caused by departure of the research and development personnel, financial officers and other key employees to the enterprise may be up to two years the employees total wages. Therefore, the payment of unemployment insurance will increase management costs for enterprises, but retain more employees and stable workforce for businesses, and the resulting invisible receipts will be far higher than the management costs.

To sum up, the impact of unemployment insurance for enterprise management is mainly positive, but there are negative impacts, for example increasing the workload of corporate human resources management. All of these make the affect of unemployment insurance for enterprise management more complex. This paper uses a multiple linear regression model to analyze the questionnaire data, studies the overall impact of unemployment insurance on enterprise management complexity.

\section{STUDY ON THE MODEL OF THE EFFECT OF UNEMPLOYMENT INSURANCE ON ENTERPRISE MANAGEMENT}

\section{A. Data sources}

In this paper, the candidates and potential candidates in the labor market on the Yangtze River Delta region are the main objects of study, and we take a survey method to get the sample data. This study distributes 500 questionnaires,
478 are returned, of which 328 are valid. Respondents' descriptive statistical analysis results are shown in Table 1:

TABLE1. RESPONDENTS' DESCRIPTIVE STATISTICAL ANALYSIS RESULTS

\begin{tabular}{llll}
\hline Statistical variables & \multicolumn{1}{c}{$\begin{array}{c}\text { Classification } \\
\text { Standard }\end{array}$} & $\begin{array}{c}\text { Number of } \\
\text { people }\end{array}$ & Proportion \\
\hline \multirow{4}{*}{$\begin{array}{l}\text { Educational } \\
\text { background }\end{array}$} & $\begin{array}{l}\text { Undergaduate } \\
\text { course }\end{array}$ & 9 & $2.74 \%$ \\
& College & 88 & $26.83 \%$ \\
& Senior & 101 & $30.79 \%$ \\
& school middle & 89 & $27.13 \%$ \\
Marital status & Junior high school & 41 & $12.50 \%$ \\
& Married & 211 & $64.33 \%$ \\
& Unmarried & 117 & $35.67 \%$ \\
Year of Birth & $1960-1969$ & 31 & $9.45 \%$ \\
& $1970-1979$ & 147 & $44.82 \%$ \\
& $1980-1989$ & 103 & $31.40 \%$ \\
& $1990-1993$ & 47 & $14.33 \%$ \\
\hline
\end{tabular}

\section{B. Research variables}

The study uses respondents' age $\mathrm{x} 1$, gender $\mathrm{x} 2$, marital status $\times 3$, staff qualifications $\times 4$ as dummy variables, insurance payment of company $\mathrm{x} 5$, $\mathrm{x} 6$ the understand extent of insurance system as regression entries, corporate image evaluation $\mathrm{y}$ as the dependent variable, from the perspective of labor to study the impact of unemployment insurance on enterprise management

\section{Model}

In this paper, a multiple linear regression model is used to analyze the impacts of unemployment insurance on enterprise management and test explanation extent of various regressions items to the dependent variable, the model specific formula is:

$$
\begin{aligned}
& \mathrm{y}_{i}=\beta_{0}+\beta_{1} x_{1 i}+\beta_{2} x_{2 i}+\cdots+\beta_{i} x_{i i}+u_{i} \\
i= & 1,2, \ldots, N
\end{aligned}
$$

In equation $1, \mathrm{~N}$ is the number of the samples, $\mathrm{y}$ is the dependent variable, $\mathrm{x}$ is independent variable, $\beta$ is the coefficient of dependent variable, and $\mu$ is the random disturbance term. Usually constant $\beta_{0}$ is seen as a dummy variable coefficient with 1 as its sample observation value. Matrix form of the model is as follow:

$$
\left(\begin{array}{c}
\mathrm{y}_{1} \\
y_{2} \\
\vdots \\
y_{N}
\end{array}\right)=\left(\begin{array}{cccc}
x_{1} & 0 & \cdots & 0 \\
0 & x_{2} & \ddots & \vdots \\
\vdots & \ddots & \ddots & 0 \\
0 & \cdots & 0 & x_{N}
\end{array}\right)\left(\begin{array}{c}
\beta_{1} \\
\beta_{2} \\
\vdots \\
\beta_{N}
\end{array}\right)+\left(\begin{array}{c}
\mu_{1} \\
\mu_{2} \\
\vdots \\
\mu_{N}
\end{array}\right)
$$

In equation $2, \mathrm{Y}$ is the $\mathrm{N}$-dimensional column vector of observation value of dependents variable, and $\mathrm{X}$ is the $\mathrm{N} \times(\mathrm{K}+1)$ matrix composed by the $\mathrm{N}$ sample points of all the independent variables. $\beta$ is $\mathrm{k}+1$-dimensional 
coefficient vector, and $\mu$ is $\mathrm{N}$ dimensional disturbance column vector. The residual sum of squares and the RSS formula of the model are as follows:

$$
R S S=\sum_{i=1}^{N} \hat{\mu}_{i}^{2}=\hat{\mu}^{\prime} \hat{\mu}=(Y-X \beta)^{\prime}(Y-X \beta)
$$

(3)

If the RSS is marked as Q, then the formula (3) can be written as:

$$
Q=\sum_{i=1}^{N} \hat{\mu}_{i}^{2}=\hat{\mu}^{\prime} \hat{\mu}=(Y-X \beta)^{\prime}(Y-X \beta)
$$

Ordinary least squares method is applied to estimate the regression coefficients. The regression coefficient vector estimated after the determination of normal equations is as follow:

$$
b=\left(X^{\prime} X\right)^{-1} X^{\prime} Y
$$

The variance of the random perturbation terms are calculated as follow:

$$
\hat{\sigma}^{2}=\frac{\sum \hat{\mu}_{i}^{2}}{N-k-1}
$$

The model uses F statistic to test the significance, and the specific formula is as follow:

$$
F=\frac{\sum_{i=1}^{N}\left(y_{i}-\bar{y}_{i}\right)^{2} / k}{\sum_{i=1}^{N}\left(\hat{y}_{i}-\bar{y}_{i}\right)^{2} /(N-K-1)}
$$

\begin{tabular}{|c|c|c|c|}
\hline \multicolumn{4}{|c|}{ Dependent Variable: Y } \\
\hline \multicolumn{4}{|c|}{ Included observations: 328} \\
\hline \multicolumn{4}{|c|}{ Convergence achieved after 3 iterations } \\
\hline R-squared & 0.9126 & Mean dependent var & 4.1151 \\
\hline Adjusted R-squared & 57.1714 & S.D. dependent var & 4.1374 \\
\hline S.E. of regression & 3.7369 & Akaike info criterion & 5.6131 \\
\hline Sum squared resid & 59.3324 & Schwarz criterion & 5.7216 \\
\hline Log likelihood & -139.0153 & Hannan-Quinn criter. & 5.8243 \\
\hline F-statistic & 1.8739 & Prob(F-statistic) & 0.0213 \\
\hline
\end{tabular}

\section{EMPIRICAL STUDY}

\section{A.Descriptive Analysis}

TABLE2. DESCRIPTIVE RESULTS

It can be inferred from Table 2 that the test value of AIC and SC are 5.6131 and 5.7216. The value of AIC and $\mathrm{SC}$ indicate that the data model in this study passes the model validation test of Akaike Information Criterion and the Schwarz Information Criterion, which means that the model in the paper is suitable for analysis of sample data. The mean dependent var y is 4.1151 and S.D. dependent var is 4.1374 , all of which indicate that the enterprise image is good to respondents. The value of R2 in statistical results is 0.9126 that show the explain parts of the regression items for the dependent variables are up to
91.3\% and regression items are appropriate. Therefore the regression results have certain reference value.

\section{B.Empirical results analysis}

TABLE3 THE IMPACTS OF UNEMPLOYMENT INSURANCE ON ENTERPRISE MANAGEMENT

\begin{tabular}{|l|l|l|l|l|}
\hline \multicolumn{5}{|l|}{ Dependent Variable: Y } \\
\hline \multicolumn{5}{|l|}{ Sample: 1328} \\
\hline \multicolumn{4}{|l|}{ Included observations: 328} \\
\hline Variable & Coefficient & Std. Error & t-Statistic & Prob. \\
\hline C & -20.3219 & 2.6086 & 7.7903 & 0.0000 \\
\hline X1 & 2.7689 & 0.5353 & 3.6558 & 0.0106 \\
\hline X2 & 1.2523 & 0.5234 & 0.5245 & 0.0497 \\
\hline X3 & 1.9073 & 0.0156 & 1.9813 & 0.9153 \\
\hline X4 & 0.2532 & 0.5956 & 1.2431 & 0.0194 \\
\hline X5 & 7.2115 & 0.6132 & 1.9546 & 0.0106 \\
X6 & 9.4216 & 0.0132 & 1.6587 & 0.0147 \\
\hline
\end{tabular}

As can be inferred from Table 3 , the variables $\mathrm{x} 1, \mathrm{x} 2$, $\mathrm{x} 4, \mathrm{x} 5$ and $\mathrm{x} 6$ pass the significance level $(5 \%)$ which illustrates the results of this study has high credibility. The coefficient of regression item is positive, and the greater regression coefficient is, the greater the influence of regression variables on the dependent variable, that is the greater the impact of the variables on the evaluation of the corporate image. It can be seen from the results that if the enterprises pay unemployment insurance for employees and candidates have a better understanding of the unemployment insurance system, the higher evaluation to the enterprise management level and the corporate image the laborers made. Comparison of estimated value and actual value of dependents variables of the model are shown in Figure 2

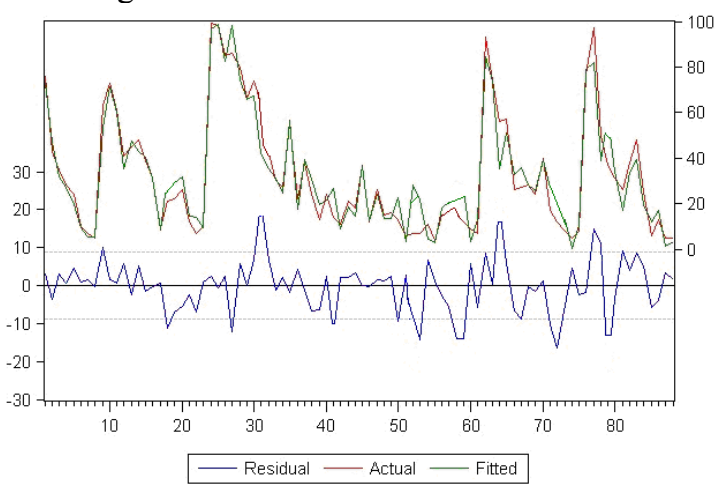

Figure 2 schematic diagrams of the actual value and estimated value of dependents variable, and residual

As can be seen from the results of impact studies, companies paying unemployment insurance will enhance enterprise competitiveness in the labor market, foster a positive image of business management, and play a positive role in enhancing the competitiveness of enterprises. Current enterprises generally encounter staff management challenges, such as recruitment difficulties, and large employees flow, enterprises should consider to improve the unemployment insurance as soon as possible and enhance enterprise competitiveness in the labor 
market. Pay unemployment insurance will increase the workload of human resources management of enterprises, but the employee information and statistics work in the unemployment insurance only increases the difficulty of management at the beginning. In summary the negative impact of unemployment insurance is far less than the positive impact it bringing to the enterprise management. Therefore enterprises are recommended to strengthen management of unemployment insurance, improve employees' social insurance management, so as to enhance the overall level of management.

\section{CONCLUSIONS}

Unemployment insurance for the temporarily unemployed workers not only is a economic income security, but also affects the enterprise image to enterprise candidates and potential candidates. While increasing management workload of corporate human resources, unemployment insurance brings a lot of hidden income for the enterprise. Therefore, enterprises should actively complete paid work of unemployment insurance and other social insurance. It provides not only a protection for employees, but also a positive impact on business management, so that enterprises and workers can get a win-win.

\section{REFERENCES}

[1]Toprak A, Güler I. Suppression of Impulse Noise in Medical Images with the Use of Fuzzy Adaptive Median Filter[J]. Journal of Medical Systems, 2006, 30(6): 465-471.

[2]Kravchonok A I, Zalesky B A, Lukashevich P V. An algorithm for median ltering on the basis of merging of ordered columns[J]. Pattern Recognition and Image Analysis,2007,17(3): 402-407.

[3]Zhang S,Karim M A.A new impulse detector for switching median filters[J].IEEE Signal Process Letters,2002,9(11):360-363.

[4]Aizenberg I,Butakoff C.Effective impulse detector based on rank-order criteria [J]. IEEE Signal Process Letters,2004,11(3):363-366.

[5] Xu H X,Zhu G X,et al.Adaptive fuzzy switching filter for images corrupted by impulse noise[J].Pattern Recognition Letters,2004,25(15):1657-1663. 